\title{
Atypical hepatic vacuolated cell lesion in the white perch Morone americana
}

\author{
A. C. Camus, R. E. Wolke
}

Comparative Animal Pathology Lab, East Farm, Department of Fisheries, Animal and Veterinary Sciences, University of Rhode Island, Kingston, Rhode Island 02881-0804, USA

\begin{abstract}
This report details histopathological findings of atypical vacuolated hepatocytes in the white perch Morone americana. Vacuolated cell lesions have been reported from a number of species in association with degraded habitats, often in the presence of hepatic neoplasms. Extensive atypical vacuolated cell lesions assuming characteristic acinar or ductular configurations have been reported previously only from the winter flounder Pseudopleuronectes americanus. Light microscopic findings, utilizing a variety of histochemical stains, suggest the identical nature of this lesion to that of winter flounder. The discovery of this lesion in a free-swimming species, feeding throughout the water column, is in direct contrast to that of the bottom dwelling pleuronectid, feeding from and constantly in contact with potentially contaminated sediments. While the winter flounder has become the sentinel fish species for pollution monitoring on the northeast coast. increased surveillance of other species may prove atypical vacuolated cell lesions represent a common mechanism of chronic cellular injury in relation to impacted environments.
\end{abstract}

Vacuolated cell lesions, hepatic and biliary, have been reported from a number of species under natural and experimental conditions (Smith et al. 1979, Hendricks et al. 1984, Cormier 1986, Grizzle \& Thiyagarajah 1988, Hinton et al. 1988). In Boston Harbor (USA) a unique lesion was reported in winter flounder Pseudopleuronectes americanus by Murchelano \& Wolke (1985); extensive areas of hepatocytes appeared replaced by atypical vacuolated cells in distinct acinar and ductular configurations. Unlike other reported vacuolated hepatocyte lesions, hepatocellular steatosis and clear cell foci, affected hepatocytes of winter flounder contain a condensed apical nucleus and a single large clear vacuole devoid of lipid, glycogen or mucopolysaccharides. The lesion also lacks the flocculent, eosinophilic material generally associated with cystic parenchymal degeneration or the locular appearance of spongiosis hepatis. Additionally, while extensive areas of hepatocytes may be replaced by hypertrophic vacuolated cells, often surrounded by connec- tive tissue, the lesion is restricted to the hepatic cords and normal architecture is generally preserved.

Since 1985, several authors have reported this lesion in winter flounder from various sites along the New England seaboard, typically in association with contaminated sediments adjacent to population centers (Zdanowicz et al. 1986, Gardner et al. 1989). Similar lesions have been noted in rock sole Lepidopsetta bilineata, starry flounder Platichthys stellatus and white croaker Genyonemus lineatus on the west coast (M. S. Meyers, National Marine Fisheries Service, Seattle, WA, pers. comm.).

Recently, an atypical vacuolated hepatocyte lesion resembling that of winter flounder was found in one of a group of 5 white perch collected from a Rhode Island coastal salt pond open indirectly to Narragansett Bay. White perch, unlike winter flounder, are found in these shallow ponds throughout the year. While capable of tolerating full seawater, they prefer the brackish waters of the ponds, where they wander and feed in small schools. In winter they congregate in deeper waters to hibernate, running up into fresh or slightly brackish water to spawn April through June. White perch are highly predaceous, feeding on the spawn and fry of numerous fish and crustaceans (Bigelow \& Schroeder 1953).

Materials and methods. Five post-spawning female white perch Morone americana were taken by fyke net in July of 1990 in a population survey of coastal salt ponds of Rhode Island, USA. Fish were euthanized in tricaine methanesulfonate (MS-222), weighed, measured and necropsied immediately. Collected tissues were identified, fixed in $10 \%$ neutral buffered formalin, embedded in paraffin and sectioned at $6 \mu \mathrm{m}$ for light microscopic examination. Staining procedures, as outlined by Luna (1968), included hematoxylin and esoin ( $\mathrm{H} \& \mathrm{E}$ ), periodic acid Schiff (PAS), Perls' method 
for iron, Masson's trichrome (MT), Ziehl-Neelsen acid fast stain $(Z N)$, and alcian blue (AB). Formalin fixed tissue was embedded in gelatin, sectioned frozen and stained for lipids with oil red O (ORO) and sudan black $B$ (SB).

Results and discussion. Fish appeared to be in good flesh, ranging in weight from 154 to $506 \mathrm{~g}$ and in length from 26 to $32 \mathrm{~cm}$. Little abdominal fat was present, but was not considered unusual for post-spawning individuals. Livers were of firm consistency and uniform light mahogany coloration. Gross observation revealed the presence of multiple $1 \mathrm{~mm}$ white foci scattered throughout the hepatic and splenic parenchymas of all fish examined. Microscopically, these were identified as the metacercariae of digenetic trematodes. Metacercariae were encircled by a thin fibrous capsule, but did not appear to elicit a significant inflammatory response.

Under light microscopy, prespawning individuals reveal large polygonal hepatocytes arranged in irrogular cords. The pattern is typical tubulosinusoidal, lacking distinct lobulation, as described in rainbow trout by Hampton et al. (1985). Nuclei are spherical and generally centrally located with dispersed chromatin and single prominent nucleoli. Most hepatocytes contain one to several inclusions within their pale, finely granular cytoplasm. Small inclusions are (PAS) positive for glycogen, while larger inclusions, often perinuclear, are (SB) and (ORO) positive for lipids. In contrast, hepatocytes of post-spawning individuals appeared small, darker staining and depleted of cytoplasmic inclusions. Shrunken hepatocytes result in an appearance of dilated sinusoids.

Atypical vacuolated hepatocytes, possessing a single large clear vacuole, occurred singly or in characteristic acinar (Fig. 1) or ductular (Fig. 2) patterns. No histological alterations were noted in hepatocytes adjacent to the vacuolated foci, nor were there any associated inflammatory changes. Nuclei were compact, uniformly basophilic and displaced apically. Occasionally, small PAS positive inclusions were present, but invariably displaced peripherally by the large central vacuole. The extensive areas of vacuolated cells were often invested in a fine sheath of connective tissue (MT). Vacuoles were consistently negative for glycogen (PAS), mucopolysaccharides (AB) and lipids (SB, ORO) as in winter flounder.

In addition to the vacuolated cell lesion, histopathological changes in the affected liver included multiple foci of necrosis, focal hepatitis, pericholangitis and vasculitis. Vacuolated cells appeared random in distribution, demonstrating no spatial relationships to any of the aforementioned lesions or metacercariae. Pericholangial fibrosis was common. A single focus of bile duct hyperplasia also contained vacuolated cells

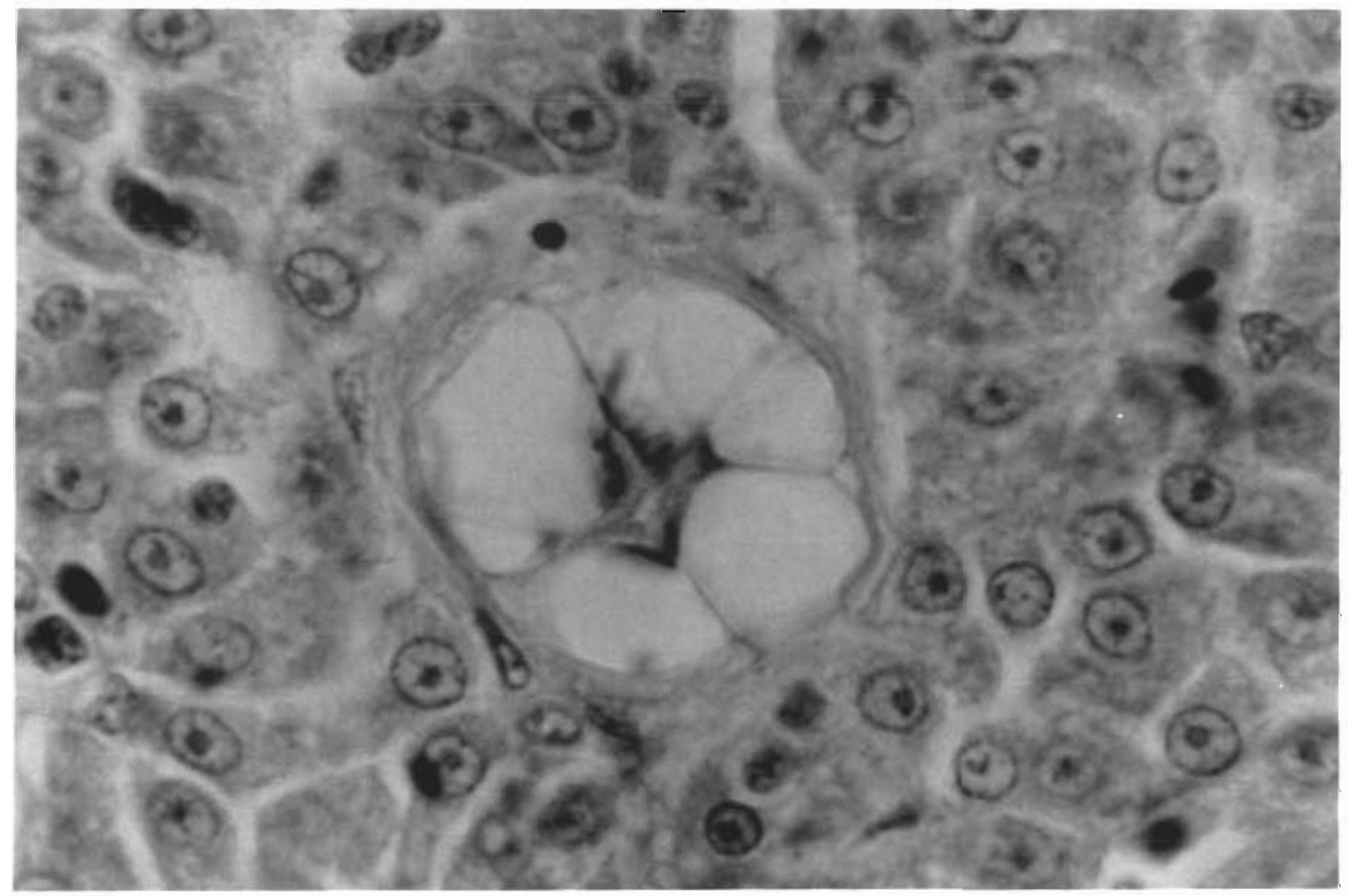

Fig. 1. Morone americana. Acinus of vacuolated hepatocytes demonstrating large central vacuoles and apically displaced nuclei. Note investing sheath of collagenous fibers. $H \& E_{i} \times 1000$ 


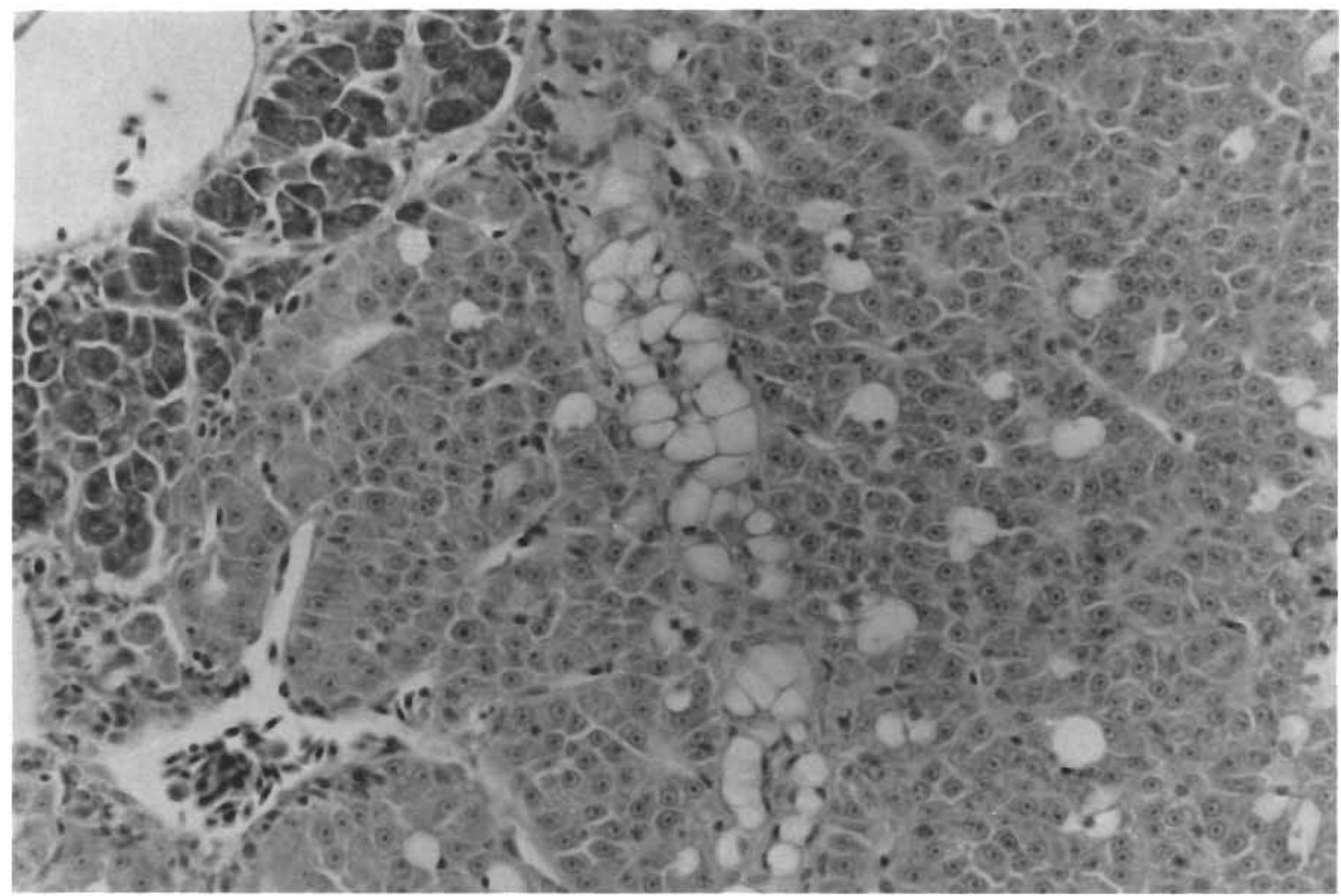

Fig. 2. Morone americana. Vacuolated cells occurring singly and in a large ductular configuration. $\mathrm{H} \& \mathrm{E}_{i} \times 500$

within its connective tissue matrix, light microscopically indistinguishable from those found in the hepatic parenchyma. Pigmented macrophage aggregates were numerous, strongly ( $\mathrm{ZN}$ ) and (PAS) positive, but only weakly Perl's positive for ferric iron. Irregular foci of coagulative necrosis contained amorphous hyalin material and single pigment laden macrophages with staining properties identical to those of nearby aggregates. Tissue coarse eosinophilic granulocytes were also common. Number, extent and severity of pathological lesions appeared to increase dramatically with fish size, even within this small sample group. The vacuolated cell lesion was present in the second largest fish, a $480 \mathrm{~g}$ specimen.

The ultrastructural characteristics of this lesion in winter flounder have recently been reviewed (Bodammer \& Murchelano 1990). The large vacuole has been determined to represent the dilated cisternae of a modified endoplasmic reticulum system. These cells show additional signs of chronic cellular injury, including numerous autophagic vacuoles and condensed mitochondria. At present, the cellular origin of this lesion and its progression remains unclear Based on cellular orientation and junctional complexes, it appears to involve both bile preductular cells (Moore et al. 1990) and hepatocytes (Bodammer \& Murchelano 1990). Likewise, the relationship of this lesion to hepatic neo- plasia is also uncertain. Flounder possessing atypical vacuolated cell lesions demonstrate a high incidence of hepatic neoplasia (Murchelano \& Wolke 1985, 1991). Statistical evidence supports a correlation between hepatic neoplasia in flatfish and polynuclear aromatic hydrocarbons (Malins et al. 1984, Gardner et al. 1989). While serial sections of the vacuolated cell liver did not demonstrate neoplasms, it did possess a variety of lesions associated with polluted environments (Meyers et al. 1987, Murchelano \& Wolke 1991).

Demonstration of an atypical vacuolated hepatocyte lesion in the white perch suggests a common mechanism of cellular injury, not unique to the winter flounder or solely bottom dwelling species. While experimental evidence is lacking, the striking cellular alterations are presumed to be the result of environmental toxins. The nature of the vacuolar contents in both species is unclear, but histochemical staining has shown them to be distinct from the more well described lipid and polysaccharide inclusions seen in other fish. Electron microscopy, in winter flounder, has identified the vacuoles as dilated cisternae of endoplasmic reticulum, often containing membranous inclusions considered autophagic in nature, a significant sign of sublethal cell injury (Bodammer \& Murchelano 1990). Clearly, electron microscopy is needed to further characterize this lesion in the white perch. Increased monitoring of non- 
traditional species as sentinels may prove this lesion more widespread than originally reported. It is hoped that discovery of this lesion in the white perch will continue to promote its evolution as a biomarker of environmental degradation.

Acknowlegements. Contribution number 2621 of the College of Resource Development, University of Rhode Island, with support of the Rhode Island Agricultural Experiment Station.

\section{LITERATURE CITED}

Bigelow, H. B., Schroeder, W. C. (1953). Fishes of the Gulf of Maine. Fishery Bulletin of the Fish and Wildlife Service, Vol. 53. U. S. Govt. Printing Office, Washington, p. 405-406

Bodammer, J. E., Murchelano, R. A. (1990). Cytological study of vacuolated cells and other aberrant hepatocytes in winter flounder from Boston Harbor. Cancer Res. 50: $6744-6756$

Cormier, S. M. (1986). Fine structure of hepatocytes and hepatocellular carcinoma of the Atlantic tomcod, Microgadus tomcod (Walbaum). J. Fish. Dis. 9: 179-194

Gardner, G. R., Pruell, R. J., Folmar, L. C. (1989). A comparison of both neoplastic and non-neoplastic disorders in winter flounder (Pseudopleuronectes americanus) from eight areas in New England. Mar. environ. res. 28: 393-397

Grizzle, J. M., Thiyagarajah, A. (1988). Diethylnitrosamineinduced hepatic neoplasms in the fish Rivulus ocellatus marmoratus. Dis. aquat. Org. 5: 39-50

Hampton, J. A., McCuskey, P. A., McCuskey, R. S., Hinton, D. E. (1985). Functional units in rainbow trout (Salmo gairdnerl) liver: I. Arrangement and histochemical properties of hepatocytes. Anat. Rec. 213: 168-175

Hendricks, J. D., Meyers, T. R., Shelton, D. W. (1984) Histological progression of hepatic neoplasia in rainbow trout (Salmo gairdneri). In: Hoover, K. L. (ed.), Use of small fish in carcinogenicity testing. National Cancer Institute Monograph No. 65, Bethesda, p. 321-326

Responsible Subject Editor: G. Peters, Hamburg, Germany
Hinton, D. E., Couch, J. A., Teh, S. J., Courtney, L. A. (1988). Cytological changes during progression of neoplasia in selected fish species. Aquat. Toxicol. 1.1 77-112

Luna, L. G. (1968). Manual of histologic staining methods of the Armed Forces Institute of Pathology, 3rd edn. McGraw-Hill Book Co. New York

Malins, D. C., McCain, B. B., Brown, D. W., Chan, S.-L., Meyers, M. S., Landahl, J. T., Prohaska, P. G., Friedman, A. J, Rhodes, L. D., Burrows, D. G., Gronlund, W. D., Hodgins, H. O. (1984). Chemical pollutants in sediments and diseases of bottom-dwelling fish in Puget Sound, Washington. Envir. Sci. Technol. 18: 705-713

Meyers, M. S., Rhodes, I. D., McCain, B. B. (1987). Pathologic anatomy and patterns of occurrence of hepatic neoplams, putative preneoplastic lesions, and other idiopathic hepatic conditions in English sole (Parophrys vetulus) from Puget Sound, Washington. J. natn. Cancer Inst. 78: 333-363

Moore, M. J., Smolowitz, R., Stegeman, J. J. (1990). Cellular alterations preceding neoplasia in Pseudopleuronectes americanus from Boston Harbor. Mar. envir Res. 28: $425-429$

Murcheiano, R. A., Wolke, R. E. (1985). Epizootic carcinoma in winter flounder, Pseudopleuronectes americanus. Science 228: 587-589

Murchelano, R. A., Wolke, R. E. (1991). Neoplasms and nonneoplastic liver lesions in winter flounder, Pseudopleuronectes americanus, from Boston Harbor, Massachusetts. Envir. Hlth Perspectives 90: 17-26

Smith, C. E., Peck, T. H., Klauda, R. J., McLaren, J. B. (1979). Hepatomas in Atlantic tomcod Microgadus tomcod (Walbaum) collected in the Hudson River estuary in New York. J. Fish Dis. 2: 313-319

Zdanowicz, V. S., Gadbois, D. F., Newman, M. W. (1986). Levels of organic and inorganic contaminants in sediments and fish tissues and prevalences of pathological disorders in winter flounder from estuaries of the northeast United States, 1984. Institute of Electrical and Electronics Engineers Oceans, 1986 Conference Proceedings. Institute of Electrical and Electronics Engineers, Washington. p. $578-585$

Revised version accepted: June 4, 1991 